\title{
Eco-innovations in V4 countries: Comparison from a Global Perspective
}

\author{
Ján Parobek ${ }^{1, *}$, Alena Rokonalová $^{1}$, Katarina Slašt'anová ${ }^{1}$, and Erika Loučanová ${ }^{1}$ \\ ${ }^{1}$ Technical University in Zvolen, Department of Marketing, Trade and World Forestry, T. G. Masaryka \\ 24, 96001 Zvolen, Slovakia
}

\begin{abstract}
Research background: Globalization and the associated growing global competition provide incentives for the adoption of new technologies and innovations. In general, innovations could be considered as a dominant driver of the economic growth. However, current environmental challenges and sustainable development support the diffusion of eco-innovations to foster green growth. In terms of its global position, a country is often compared to its neighbouring countries, which are often the most important trading partners in the international market.

Purpose of the article: This paper is focused on the evaluation of ecoinnovation performance of the V4 countries with emphasis on the Slovak Republic.

Methods: The article applies selected indicators of the Global Innovation Index to provide insightful data on countries' eco-innovation performance from the different V4 countries by applying the correlation analysis.

Findings \& Value added: The results compare the state of selected indicators of innovation within the V4 countries and describe the current position of the Slovak Republic. The results demonstrate the relative strengths within all selected countries in the sub-pillar Ecological Sustainability and significant eco-innovation potential.
\end{abstract}

Keywords: ecological innovation, sustainability, globalisation

JEL Classification: F64, O00, $Q 01$

\footnotetext{
*Corresponding author: parobek@tuzvo.sk
} 


\section{Introduction}

The globalisation inherently is as old as human society. Many authors focused on interconnection between globalisation, innovations and sustainable development. (Wield, 2013; Golembiewski et al., 2015; Socaciu, 2014; Loucanova et al., 2021; Olsiakova et al., 2015; Gygli et al., 2019) Technological innovations have improved awareness focused on globality, and have created much of the necessities that have accelerated its development. However, an explanation of globalisation that considers only technological determinism and rationalism has become redundant (Ukpere, 2010). These authors have analysed different key drivers of globalisation. They deal with that the 'Supreme Mandate' as the most critical factor of globalisation. However, technological innovations contribute to more environmentfriendly production practices. On the other side, the market for eco-innovation very much depends on government's environmental policies and instruments (standards, taxes, tradable permits, subsidies, communication, and covenants). The realisation of global innovations cannot be achieved through national policies alone, therefore international policies are needed.

Pichlak (2016) analysed the broad sets of factors that influence the innovation adoption process in the environmental, organizational, top managers' innovation, globalisation and user acceptance context. The innovation adoption process is presented as a sequence of stages, progressing from initiation through adoption decision to implementation of an innovation and it is considered at the organizational level. She recognised that the considered factors do not affect the innovation adoption process with the same strength but exert varying levels of influence on the subsequent stages. Kemp et al. (2012) analysed international nongovernmental organisations (NGOs) action with the help of the analytical framework of exit, voice, and loyalty. Innovations can be consider as one of the most significant drivers to support political and environmental maintenance needed to meet the sustainability approaches according to the bioeconomy values. However, local strategies pressure the environmental benefits of eco- innovation, not all innovations lead to improve in terms of sustainability. Consequently, eco - innovations need a measured and flexible plan to approach the transition in the suitable way.

In the global point of view eco-innovation appeared as an idea to implement sustainable development during the RIO+20 conference. Researches have established strategies for ecoinnovation as one way to sustainable development. At the present time eco-innovation are developing also in the developing countries. Jang et al. (2014) described eco-innovation policies in developing countries. They investigated policies related to sustainable development in 17 Asian countries with the categories of policy instruments. In their research, national policies are compared with the classification of development stages according to the World Economic Forum (WEF). Their results indicated different approaches to eco-innovation and contributed to facilitating and diffusing eco-innovation toward sustainability in Asia.

Some authors tried to identify interconnection between environmental aspects and innovations. Pichlak and Szromek (2021) have done empirical research to analyse the environmental aspects of innovation activity undertaken by companies and, in particular, to assess sustainable business leaders' propensity to generate eco-innovation. They applied nonrandom sample and used the Computer Assisted Telephone Interview (CATI) among 54 of the most eco-innovative Polish companies. According to their results, polish companies more likely to generate radical rather than incremental changes. Furthermore, the most ecoinnovative companies are those developing technologies for environmental protection. They confirmed that bigger companies have a higher propensity to develop incremental and radical eco-innovation and an open innovation strategy strengthens the propensity to generate ecoinnovation. Moreover, developing such deviations is dominated by the implementation of 
strategic supply chain collaboration, concerning the absorption of knowledge and information issuing from the global market.

The research revealed that the bioeconomy development in Lithuania has been regulated and promoted through certain sectoral policies: agriculture, forestry, fisheries, energy, environment (including waste management), scientific research, innovation and biotechnology development. Vitunskiene et al. (2017) described that bioeconomy strategy development can be motivated by country's specialization and, compared with other EU member states, strong performance in terms of recent growth in all biomass production and fully bio-based manufacturing sectors. They decomposed these drivers into global, European and national. Applying content analysis of European countries' bioeconomy strategies, they identified the key drivers: common EU bioeconomy policy, strategy and action plan; assurance of biomass availability and sustainability, as well as efficient biomass value chain; the need to strengthen markets and competitiveness of the bioeconomy subsectors; the necessity of close cooperation among all stakeholders; the need of the development of new technologies.

There is a lack of studies that would compare the development of these indicators between countries. The aim of the article is to compare eco-innovation performance of the V4 countries. We apply selected indicators to compare the state of innovation within the V4 countries and describe the current position of the Slovak Republic. Our results try to identify the position within all selected countries in the sub-pillar Ecological Sustainability and significant eco-innovation potential. The results will offer a frame for international cooperation in eco-innovation activities, especially in the period of a post-pandemic recovery of the economy.

\section{Methodology}

The research focuses on the identification of the impact of globalisation on the development of eco-innovation in V4 countries. The value of the Global Innovation Index (GII) was analysed in the all V4 countries. The three indicators under the innovation sub-pillar ecological sustainability, namely GDP per unit of energy use, Ecological performance and ISO 14001 environmental certificates, were compared with the GII. The GDP per unit of energy use indicator monitors the impacts of energy policies, forecast energy demand, study the evolution of the domestic energy market, and evaluate possible areas for action. Environmental performance is based on 24 indicators that assess the environmental health and vitality of the ecosystem in countries. They are part of the Environmental Performance Index (EPI). ISO 14001 certificates determine the requirements for an environmental management system (Jacomossi et al., 2021).

The reports published by the Global Innovation Index are significant comparative tool on the state and development of innovation in individual countries of the world. The index consists of 80 indicators. Scores range from 0 to 100 points, with the higher the score, the better the rating. The GII provides insightful data on innovation and, in turn, to assist economies in evaluating their innovation performance and making informed innovation policy considerations. The GII influences policymakers who are referring regularly to innovation and their innovation rankings as part of their economic policy strategies. Additionally, the UN, as noted in its resolution on Science, Technology and Innovation for achieving Sustainable Development Goals (SDGs) applies the GII for measuring innovation. Second, the GII allows economies to assess their innovation performance. Third, the GII continues to give a strong impetus for economies to prioritize and collect innovation metrics. By experimenting with new data and evaluating existing innovation metrics, the GII also aims to shape the innovation measurement agenda (Global Innovation Index, 2020). 
In this research, the GII is applied as an independent variable. Further, the Innovation sub-pillar, namely the sub-pillar Ecological Sustainability and its indicators are examined and used as dependent variables. Data is drawn from the Database of Global Innovation Index 2020 Indicators (Global Innovation Index, 2020; The Global Economy, 2021).

The Pearson $r$ (1) correlation was used to examine the relationship between the GII and the innovation sub-pillars of in V4 countries. The following formula was used:

$$
r=\frac{\sum_{i}\left(x_{i}-\bar{x}\right)\left(y_{i}-\bar{y}\right)}{\sqrt{\sum_{i}\left(x_{i}-\bar{x}\right)^{2}} \sqrt{\sum_{i}\left(y_{i}-\bar{y}\right)^{2}}}
$$

The hypothesis $\mathrm{H}_{0}$ assumes no association between the GII and the innovations indicators in V4 countries. On the other hand, alternative hypothesis $\mathrm{H}_{1}$ assumes that there is an association between the development of globalisation and the innovations indicators in V4 countries. The statistical program SPSS was applied to verified mentioned statistical hypotheses, using the level of significance $\alpha=0.05$.

\section{Results and Discussion}

Visegrad Group countries have not only a similar history, but also similar economic development, which nowadays is supported by innovative activities. At present, environmental challenges put the emphasis on shifting from general form of innovation to eco-innovation. Jacomossi et al. (2021) explored the relationship between competitiveness, environmental sustainability and innovation activities. Their study shows that the complementarity of these dimensions cannot be overestimated or overlooked. The study points to the need for balance and shows that a rational approach to these elements is key to the prosperity of countries.

GII data show that in 2020 the innovativeness of the V4 countries was low. The value of the innovation index of three of the Visegrad Group countries was below the EU average 46.93 points (The Global Economy, 2021). Exception is the Czech Republic with the highest value of 48 points. Poland, Slovakia and Hungary are referred to the group of so-called "catching-up countries". However, the innovation rate in these countries did not exceed 50 points out of 100 possible (Global Innovation Index, 2020).

As already mentioned, the highest GII value was recorded in the Czech Republic, which produces more innovation outputs relative to its level of innovation investments. The Czech Republic continues to excel in areas related to its manufacturing industries, registering strengths in knowledge absorption and diffusion. It ranks among the top 10 in high technology imports. It has also improved in the area of creative goods and services. Considering subpillar Ecological sustainability, the Czech Republic continues to rank among the top 10 in the indicator of environmental certificates.

On the contrary, the Slovak Republic reached the lowest value of GII among the V4 countries in the analysed period. The main reasons are the insufficient amount of state expenditure on education, research and development, which, despite the constant increase, does not reach even half of the EU average (Fabova, 2016). The low share of public and private support for research and development activities as well as the fragmented institutional framework of eco-innovation are considered as main shortcomings. The number of patents related to eco-innovation remains very low, as does the media coverage of eco-innovation and the circular economy. Moreover, the low share of exports of products from ecoinnovative industries and the low added value in environmental protection and resource management activities are noted (Loucanova et al., 2021; Broering et al., 2020) . However, similarly as Czech Republic, Slovakia produces more innovation outputs relative to its level of innovation investments (Global Innovation Index, 2020). 
The GII pays special attention to presenting a scoreboard for each economy, which includes strengths and weaknesses. According to the GII 2020 report, for a given economy, strengths are those scores with percent ranks greater than the 10th largest percent rank among the 80 indicators in that economy (Global Innovation Index, 2020). Of the selected countries, Slovakia, the Czech Republic and Hungary, show strengths within the subpillar Ecological sustainability. The table 1 shows that the examined countries show strengths, especially in the indicator of ISO 14001 environmental certificates adopted by companies and promoting environmental protection and pollution prevention.

By examining the relationship between the value of GII and its selected indicators of the V4 countries, applying a selected level of significance, differences were determined. All results were statistically significant at the alpha 0.05 significance level. The research revealed a strong negative dependence between the energy intensity indicator of the economy and the variable GII, when the value of $\mathrm{r}-0.9532$ was reached (see Table 1). This strong degree of association means that the higher the energy intensity of the V4 countries, the more the corresponding GII value decreases. The efficiency of the economies of the V4 countries is understood as the energy intensity of final energy consumption in selected sectors. However, current environmental challenges call for increasing energy efficiency. Individual country's decisions need to be coordinated to eliminate barriers to energy efficiency. Investment in breakthrough energy technologies is essential for sustainable development. In EU member states, energy intensity has decreased in recent years. It was in the countries of Central and Eastern Europe that the largest decline is due to changes in their economic structure.

In contrast, the indicators Ecological performance and ISO 14001 environmental certificates showed a slight positive linear correlation, with the value of the Pearson coefficient approaching 0.7 in both cases. This leads to the conclusion that the use of the principles of ecological sustainability and the application of eco-innovation have a positive impact on the GII level. According to the data, we can confirm the hypothesis $\mathrm{H}_{1}$ assumes that there is an association between the development of globalisation and the innovations indicators in V4 countries. From a global perspective, environmental policy goals designed in the Paris Climate Agreement and the United Nations Sustainable Development Goals (SDGs) play an important role in development of eco-innovations among countries (Broering et al., 2020). The growth of eco-innovation performance ultimately has a positive impact on the development of GII.

Table 1. Selected indicators of Global Innovation Index in V4 countries

\begin{tabular}{|c|c|c|c|c|}
\hline & \multicolumn{3}{|c|}{ Ecological sustainability } & \multirow{2}{*}{ GII } \\
\cline { 2 - 4 } & $\begin{array}{c}\text { GDP per unit } \\
\text { of energy use }\end{array}$ & $\begin{array}{c}\text { Ecological } \\
\text { performance }\end{array}$ & $\begin{array}{c}\text { ISO 14001 } \\
\text { environmental } \\
\text { certificates }\end{array}$ & \\
\hline Slovakia & 28,6 & 68,3 & $\mathbf{7 0 , 5}$ & 39,7 \\
\hline Czech Republic & 21,7 & 71 & $\mathbf{8 6 , 1}$ & 48,3 \\
\hline Hungary & 29,7 & 63,7 & $\mathbf{6 1 , 2}$ & 41,5 \\
\hline Poland & 29,3 & 60,9 & 19 & 40 \\
\hline Correlation & $\mathbf{- 0 , 9 5 3 2}$ & $\mathbf{0 , 6 8 6 7 4 1}$ & $\mathbf{0 , 6 4 2 6 6 6}$ & $\mathbf{1}$ \\
\hline
\end{tabular}

\section{Conclusion}

The V4 countries are not among the world leaders in the field of innovation. Among the countries discussed, the Czech Republic occupied the highest position from the globalisation point of view. The research used indicators of ecological sustainability found in the GII. The 
trend of sustainable development is becoming stronger and the transition to a low-carbon and resource-efficient circular economy is considered necessary. At present, innovations that support sustainable development are one of the main topics at a global level. The research revealed that there is an association between the ecological sustainability indicators and corresponding GII value. Increasing trends in eco-innovative activities from a global perspective may affect GII in a positive way. However, we can conclude that eco-innovation market in V4 countries is at its initial stage of development. Moreover, it is important to note that in the V4 countries there is potential for further development and overall improvement in this area. Strategic solutions at the political level need to be developed to improve the conditions for developing eco-innovation.

\section{Acknowledgements}

The authors are grateful for the support of the Scientific Grant Agency of the Ministry of Education, Science, Research, and Sport of the Slovak Republic, Grant No. 1/0666/19 Determination of the Development of a Wood-based Bioeconomy and Grant No. 1/0674/19 Proposal of a model for the eco-innovation integration into the innovation process of companies in Slovakia in order to increase their performance.

\section{References}

1. Broering, S., Laibach, N., \& Wustmans, M. (2020). Innovation types in the bioeconomy: Journal of Cleaner Production, 266, 121939.

2. Fabová, L. (2016). Root causes of the Slovak Republic in innovation development. Journal of Knowledge Society, 2 (4).

3. Global Innovation Index https://www.globalinnovationindex.org

(2020). $\quad$ Retrieved

4. Golembiewski, B., Sick, N., \& Broering, S. (2015). The emerging research landscape on bioeconomy: What has been done so far and what is essential from a technology and innovation management perspective? Innovative Food Science \& Emerging Technologies, 29, 308-317.

5. Gygli, S., Haelg, F., Potrafke, N., \& Sturm, J. E. (2019). The KOF Globalisation Index - revisited. Review of International Organizations, 14(3), 543-574.

6. Jacomossi, R. R. et al. (2021). Does Ecological Sustainability Really Matter? Evaluation of Its Mediating Role in the Relationship between Innovation and Competitiveness. BAR - Brazilian Administration Review, 18(3).

7. Jang, E. K., Park M. S., Roh T. W., Han K. J., Jo, J. H., \& Kim, S. H. (2014). EcoInnovation Policies Toward Sustainability in Asian Countries. World Sustainability Forum 2014 - Conference Proceedings Paper .

8. Kemp, R., Soete, L., \& Weehuizen, R. (2012). Towards an Effective Eco-Innovation Policy in a Globalised Setting. Handbook of globalisation and environmental policy. National government interventions in a global arena, $2^{\text {nd }}$ edition, 211-240.

9. Loučanová, E., Šupín, M., Čorejová, T., Repková-Štofková, K., Šupínová, M., Štofková, Z., \& Olšiaková, M. (2021). Sustainability and Branding: An Integrated Perspective of Eco-innovation and Brand. Sustainability, 13(2), 732.

10. Olšiaková, M., Šupín, M., Dovčíková, A., \& Triznová, M. (2015). Murketing and its Application in Practice. Globalization and Its Socio-Economic Consequences, 549. 
11. Pichlak, M. (2016). The innovation adoption process: A multidimensional approach. Journal of Management \& Organization, 22 (4), 476-494.

12. Pichlak, M., Szromek, A.R. (2021). Eco-Innovation, Sustainability and Business Model Innovation by Open Innovation Dynamics. Journal of Open Innovation: Technology, Market, and Complexity, 7 (2), 149.

13. Socaciu, C. (2014). Bioeconomy and green economy: European strategies, action plans and impact on life quality. Bulletin of the University of Agricultural Sciences and Veterinary Medicine Cluj-Napoca Food Science and Technology, 71 (1), 1-10.

14. The Global Economy (2021). Innovation index in Europe. Retrieved from: https://www.theglobaleconomy.com/rankings/gii_index/

15. Ukpere, W. I. (2010) Rationalism, technological innovations and the supreme mandate in the process of globalisation. African Journal of Business Management, 4 (4), 467-474.

16. Vitunskiene, V., Alekneviciene, V., Ramanauske, N., Miceikiene, A., Caplikas, J., Kargyte, V., Makuteniene, D., \& Jazepcikas, D. (2017). Global, European and national drivers of Lithuanian bioeconomy strategy. 8th International Scientific Conference on Rural Development - Bioeconomy Challenges, Aleksandras Stulginskis Univ, Akademija, 1391-1399.

17. Wield, D. (2013). Bioeconomy and the global economy: industrial policies and bioinnovation. Technology Analysis \& Strategic Management, 25(10), 1209-1222. 